\title{
ZAŁOŻENIA REALIZMU ONTOLOGICZNEGO I AKSJOLOGICZNEGO W KONCEPCJI WYCHOWANIA JACKA WORONIECKIEGO
}

\author{
Assumptions of ontological and axiological realism in Jacek Woroniecki’s concept of \\ education
}

\begin{abstract}
Summary: The following paper presents Woroniecki's concept of education that harkens back to the achievements of Christian and classical thought. It is based on ontological and epistemological realism in declaring the necessity of integral and universalist human education and training. This pedagogy is based on the assumptions of philosophical anthropology, and Aristotelian and Thomaston ethics; approaches which present who a man is and what moral goodness is as an aim of human struggle. This aim is simultaneously the aim of pedagogy, and thus all undertakings and ways of supporting the learner are to be subordinated to this aim. We can attribute to Woroniecki's pedagogical views, apart from category realism, the more general category of universality. Pedagogy, perceived as educational ethics integral to all human education and training, can be understood as being addressed to everyone. The realism of this pedagogy is based on the conviction that everyone should develop in one's individual and social life in accordance with one's potential, which should be realized by working on oneself.
\end{abstract}

Key w ord s: Jacek Woroniecki, ethics of education, neo-Thomism, ontological realism, epistemological realism, aretology

Jacka Woronieckiego (1878-1949) ${ }^{1}$ koncepcja wychowania wyrasta z czterech źródeł: klasycznej paidei, antropologii i etyki Arystotelesa oraz Tomasza z Akwinu, a także autorytetu Pisma Świętego. Osadzona jest na realizmie ontologicznym i teoriopoznawczym w głoszeniu konieczności integralnego, uniwersalistycznego wychowania oraz kształcenia człowieka. Pedagogika rozumiana realistycznie nie może się obejść bez antropologii filozoficznej i etyki, które ukazują, kim jest człowiek,

\footnotetext{
${ }^{1}$ O. Jacek Woroniecki był osobą wyjątkową. O. Feliks W. Bednarski we wspomnieniach swego mistrza, pisze o nim, iż „[w]ychowywał promieniowaniem osobistego charakteru, którym z łatwością podbijał sobie serca, przykładem własnego życia, konferencjami, rekolekcjami, kazaniami do ludu, słuchaniem spowiedzi, wykładami oraz swą twórczością literacką, którą niemal bez reszty poświęcał zagadnieniom wychowawczym, gdyż nawet jego studia z innych dziedzin miały służyć wychowaniu”. Feliks W. Bednarski, Zagadnienia pedagogiczne (Londyn: Katolicki Ośrodek Wydawniczy Veritas 1982), 59.
} 
a także czym jest dobro moralne jako cel ludzkiego dążenia. Jest ono jednocześnie celem pedagogiki, któremu podporządkowane są wszystkie zadania i sposoby wychowawczego wspierania podopiecznych.

Czerpiąc z dorobku myśli chrześcijańskiej i klasycznej, Woroniecki łączy wharmonijną całość twórczy rozwój każdego człowieka z szacunkiem do uniwersalnych norm moralnych, życia codziennego z jego wymiarem religijnym ze względu na cel uwzględniający porządek nadprzyrodzony ujawniający się w życiu człowieka, w jego miłości skierowanej ku ludziom i Bogu². Pedagogika ta zakłada integralne wychowanie oraz kształcenie człowieka i jest skierowana do wszystkich. Jej realizm osadza się na przeświadczeniu, iż każdy powinien w życiu osobistym i społecznym doskonalić się z racji swej potencjalności, którą należy urzeczywistnić. Dlatego wymagania tej pedagogiki, chociaż są ogólne, to jednak potrzebują konkretyzacji wodniesieniu do każdego człowieka. Z kolei integralność i wszechstronność oddziaływań wychowawczych ma doprowadzić do ukształtowania moralnie dobrego człowieka o właściwie ukierunkowanych sprawnościach, zdolnego w każdej sytuacji podejmować odpowiedzialnie najlepsze decyzje w kierowaniu tak samym sobą, jak i innymi3.

\section{Zarys struktury teoriopoznawczej w pedagogice Woronieckiego}

W zrozumieniu założeń realistycznej pedagogiki Woronieckiego pomocne są wyjaśnienia dotyczące nabywania stałych usposobień do zachowania się w różnych sytuacjach. Zagadnienie to domaga się osadzenia w problematyce etycznej i antropologicznej. Woroniecki powołuje się na klasyczną, arystotelesowsko-tomistyczną koncepcję etyczno-antropologiczną, uwzględniającą praktyczne cele wychowawcze i wskazującą na dobre zasady postępowania wraz z wyjaśnieniem przyczyn istnienia dobrych oraz złych czynów4. Jej wartością jest to, że ukazuje sposoby i uczy właściwego doboru środków prowadzących do nabycia trwałych usposobień, dzielności oraz umiejętnego radzenia sobie w przezwyciężaniu zaistniałych już wad5.

\footnotetext{
${ }^{2}$ Jacek Woroniecki, „Pełnia modlitwy”, w: tegoż, Wychowanie czlowieka. Pisma wybrane (Kraków: Znak 1961), 108-114.

${ }^{3}$ Umiejętność kierowania oraz rządzenia sobą i innymi jest wyrazem zdobytej cnoty roztropności, czyli umiejętności rządzenia, a także rozkazywania, która jest potrzebna wszystkim osobom prowadzącym działalność nauczycielską, rodzicielską czy jakąkolwiek działalność społeczną i polityczną. Szerzej na ten temat w: Jacek Woroniecki, Umiejętność rządzenia i rozkazywania (Poznań: Albertinum 1947).

${ }^{4}$ Należy zauważyć, iż obecnie podejmowane dyskusje dotyczące moralnej kondycji podmiotu w ramach etyki cnót są kolejnym etapem rozwoju klasycznej aretologii, zob. np.: Alasdair MacIntyre, Dziedzictwo cnoty. Studium z teorii moralności, przekł. Adam Chmielewski (Warszawa: PWN, 1996); Jacek Jaśtal, Natura cnoty. Problematyka emocji w neoarystotelesowskiej etyce cnót (Kraków: Księgarnia Akademicka 2009); Natasza Szutta, „Statut współczesnej etyki cnót”. Diametros 1 (2004): 70-84; tejże, „Dyskusja z sytuacjonistyczną krytyką etyki cnót. Odpowiedź na zarzuty Gilberta Harmana”. Diametros 31 (2012): 88-112.

${ }^{5}$ Jarosław Horowski, „Sprawność czy kompetencje moralne?”. Paedagogia Christiana 1 (2012): 192-198.
} 
Woroniecki jest przeświadczony, że działania wychowawcze powinny wynikać przede wszystkim ze zrozumienia działań moralnych. Mając na uwadze realistyczną pedagogikę odwołującą się do założeń teoriopoznawczych, oprócz wyodrębnienia poszczególnych władz psychicznych, dokonamy ogólnego omówienia ich działań ${ }^{6}$.

W psychice ludzkiej wyróżnia się dwa poziomy: zmysłowy i umysłowy. Na każdym z nich rozróżniamy dwie odrębne funkcje władz psychicznych: poznawcze i pożądawcze. Mimo dużego uzależnienia od siebie tych dwóch poziomów, są one w istocie zupełnie inne. Występujące na każdym funkcje poznawcze i pożądawcze również zdecydowanie się od siebie różnią.

Procesy zachodzące na poziomie zmysłowym są bardziej zróżnicowane i złożone od tych z poziomu umysłowego. Zewnętrzne i wewnętrzne poznanie zmysłowe ma szereg swoistych, odrębnych procesów, jak to ma miejsce przykładowo w funkcji pożądawczej obejmowanej terminem „uczucie”. Na poziomie umysłowym funkcje poznawcze i pożądawcze są bardziej proste, jednolite - rozum wszystko w sobie odtwarza, a wola sama jest motorem wszelkich naszych czynności oraz źródłem wszelkiego chcenia.

W wychowaniu szczególną uwagę należy zwrócić na dziedzinę dążeń zmysłowych, wyznaczaną przez uczucia stanowiące podstawę, bazę dla dążeń umysłowych, a mianowicie woli. Podobnie jak intelekt korzysta ze sfery zmysłowopoznawczej, tak samo wola wykorzystuje i opanowuje dziedzinę uczuć. Uczucia same w sobie są moralnie obojętne. Jeśli jednak nie podlegają władzy woli oraz intelektu, wtedy przejmują rolę czynników kierujących naszym życiem, postępowaniem i twórczością, a to jest moralnie niewłaściwe, a nawet szkodliwe. Człowiek powinien dążyć do tego, aby umiejętnie wykorzystywać w życiu uczucia, wychowując je, co polega na ich opanowywaniu.

Życie umysłowe kierowane jest przez rozum, a wykonywane przy udziale woli. Władza woli i rozumu wzajemnie się przenika. Cechą władzy woli jest reagowanie tylko na dobro, ale jeśli prawda i jej poznanie przedstawiają jej się także jako dobro człowieka, to dąży ona do poznania prawdy, pobudzając w tym celu rozum do właściwej mu czynności poznawczej. Rozum z kolei reaguje tylko na prawdę, ale jeśli prawda ta zawiera się we wszystkim, także i w dobru, które może być prawdziwe, to rozum zajmuje się tym dobrem, bada jego prawdziwość i przedstawia woli jako przedmiot jej chcenia. Oznacza to, że działalność każdej z tych władz może być przedmiotem aktywności drugiej.

Działalność umysłowo-poznawcza jest także istotna dla celów wychowawczych. Sprowadza się do tworzenia pojęc i sądów oraz przeprowadzania rozumowań. Dwie pierwsze aktywności są ważne w rozwoju człowieka, gdyż dotyczą zdobywania mądrości wyrażającej się w zdolności refleksji filozoficznej (sądzenia). Jednak nasza kultura techniczno-naukowa marginalizuje te dwa obszary działań na rzecz rozwoju

\footnotetext{
${ }^{6}$ Jacek Woroniecki, Katolicka etyka wychowawcza, Etyka ogólna, t. I (Lublin: Redakcja Wydawnictw KUL 1995), 98-108.
} 
czynności rozumowania. Sytuacja ta sprowadza pedagogikę do podejmowania działań skrajnie racjonalistycznych przy jednoczesnym zaniedbywaniu rozwoju intelektualnego wychowanków7\%

Woroniecki wiele krytycznych uwag poświęca błędnemu w skutkach oddzieleniu się w renesansie pedagogiki od etyki. Okazuje się, że samodzielność zdobyta przez tę pierwszą nie przełożyła się na jej postęp w porównaniu z wcześniejszym okresem rozwoju. Wielu pedagogów zarzuciło problematykę wychowania moralnego, koncentrując się głównie na dydaktyce, której naturalnym miejscem w średniowieczu była psychologia. Oceniając tę sytuację z dzisiejszej perspektywy, można stwierdzić, iż tak powstała pedagogika, łącząc w sobie naukę o wychowaniu i kształceniu, zdobyła tylko względną jedność. Można jedynie mówić o niej w sensie materialnym, gwarantuje ją podmiot, uczeń-wychowanek potrzebujący jednocześnie i wychowania, i wykształcenia. Pedagogika wyrwana z naturalnego środowiska badań etycznych utraciła swe macierzyste podłoże. Etyce z kolei odebrano najważniejszy jej dział i możliwość empirycznego potwierdzania promowanych $\mathrm{w}$ wychowaniu wartości moralnych. Przyjmowano naiwnie, iż pedagogika oderwana od założeń etycznych jest koniecznym i jedynym warunkiem rozwoju życia indywidualnego oraz społecznego. Efekt był odwrotny. Szerzeniu oświaty często nie towarzyszyło pogłębienie życia moralnego, a w miejsce prawdziwej społecznej demokratyzacji wdarła się powierzchowna i mało wartościowa kultura intelektualna, u podstawy której przyjęto idee pozytywizmu i neopozytywizmu. W tym stadium pedagogika przetrwała do dziś i administracyjnie jest przyporządkowywana jedynie obszarowi nauk społecznych, a nie humanistycznych.

Usamodzielnianie się pedagogiki zbiegło się z nowożytnym intelektualizmem i empiryzmem, które na pedagogice wywarły wpływ ujemny, nadając jej charakter bardzo jednostronny i ograniczając do kształcenia. Działalność pedagogiczna w kontekście wąsko rozumianego intelektualizmu, przyznającego rozumowi pierwszeństwo i rolę kierowniczą w organizowaniu oraz kierowaniu wychowaniem ucznia, polega niemal wyłącznie na czynnościach poznawczych, z wykluczeniem obecności czynników pożądawczych, w tym - woli.

W nowożytności filozofowie i pedagodzy przyjmujący stanowisko intelektualizmu przez termin „wola” lub „chcenie” rozumieli odrębny czynnik, element lub czynność naszej psychiki, zatem przypisali mu znaczenie poznawcze, związane z ludzką zmysłowością̧ ${ }^{8}$. Wśród pierwszych nowożytnych pedagogów odwołujących się szczególnie do kształcenia wymienić można między innymi Szymona Marycjusza i Jana Amosa Komensky9. Pomijanie w wychowaniu władz pożądawczych skutkowało zdobywaniem wiedzy, opanowywaniem norm rządzących

\footnotetext{
${ }^{7}$ Tamże, 18-31.

${ }^{8}$ Źródłem nowożytnego intelektualizmu pedagogicznego jest filozofia Kartezjusza, który błędnie określił stosunek duszy do ciała, substancji myślącej do rozciągłej. Uwikłał się przez to w nierozwiązywalny problem mind-body, przy jednoczesnym przyjęciu skrajnego dualizmu.

${ }^{9}$ Sławomir Sztobryn, „Historia wychowania”, w: Pedagogika. Podstawy nauk o wychowaniu, t. I, red. Bogusław Śliwerski (Gdańsk: Gdańskie Wydawnictwo Pedagogiczne 2006), 46-47, 58-60.
} 
ludzkim postępowaniem, co rzeczywiście jest koniecznym warunkiem, ale nie stanowi jego istoty i nie wyczerpuje całego zakresu zadań wychowawczych.

\section{Założenia aretologiczne pedagogiki Woronickiego}

Pedagogiczna koncepcja Woronieckiego skierowana jest na osobiste i społeczne doskonalenie się osób pod względem moralnym, a to wymaga właściwego ukształtowania ich woli. „Wychowanie zwraca się w pierwszej linii do władz pożądawczych, tj. do woli i do uczuć, i im to właśnie ma nadać te różne wewnętrzne sprawności do czynu, które nazywamy cnotami. Zajmuje się także ono i działalnością rozumu, ale nie jego funkcjami czysto poznawczymi, lecz tymi, za pomocą których kieruje on uczynkami i które z tej racji są ściśle związane z działalnością władz pożądawczych woli i uczuć"10.

Sprawnościami rozumu ściśle uzależnionymi od woli są roztropność i wiara. Warto podkreślić, że w wychowaniu Woroniecki nie zajmuje się działalnością poznawczą zmysłów, dlatego, że działalność ta nie dotyczy moralności. „Pośrednio wszakże interesuje się wyrobieniem i opanowaniem pamięci i wyobraźni jako współczynników kierowniczej działalności rozumu praktycznego i składników roztropności. Etykę bardzo zajmują rozmaite podniety związane z poznawczą działalnością zmysłów, i ujęcie ich w pewne karby należy niewątpliwie do dziedziny wychowania; ale te podniety, które towarzyszą działalności wszystkich naszych władz psychicznych, należą właściwie do dziedziny pożądania. Zadaniem przeto wychowania nie jest wyrobić wzrok i słuch i wzbogacić wyobraźnię i pamięć, ale nauczyć panować nad nimi i związanymi z nimi podnietami, tak iżby nie one nami rządziły i popychały nas, gdzie zechcą, ale abyśmy je mieli całkowicie w ręku i mogli się nimi posługiwać do celów, wskazanych przez rozum"11.

Wykształcenie, przeciwnie do wychowania, w pierwszym rzędzie doskonali funkcje poznawcze zmysłów, pamięci, wyobraźni i rozumu. W rezultacie osiągamy umiejętność dokładnego zmysłowego obserwowania połączonego z przechowywaniem wszystkiego w pamięci, sprawnego odtwarzania zgromadzonych danych oraz przetwarzania ich w różnych formach przez wyobraźnię i poznawania przez rozum. Zdobywane sprawności w używaniu tych władz poznawczych łączą się z umiejętnością korzystania z gromadzonych wiadomości, informacji. Wykształcenie nie wiąże się jednak bezpośrednio z pracą nad usprawnieniem władz pożądawczych, choć pośrednio jest od nich w dużym stopniu zależne. Zależność ta w głównej mierze dotyczy opanowania podniet pożądawczych związanych zdziałalnością władz poznawczych. Trzeba też wiedzieć, że porządnie przeprowadzone nauczanie swą systematycznością i porządkiem wywiera silny wpływ wychowawczy. Zdaniem

\footnotetext{
${ }^{10}$ Woroniecki, Katolicka, 344.

${ }^{11}$ Tamże, 344-345.
} 
Woronieckiego harmonijne współdziałanie wychowania $\mathrm{z}$ wykształceniem jest absolutnie konieczne ${ }^{12}$.

Nabywane w procesie wychowania sprawności mają doprowadzić wychowanka do samodzielności, samowychowania i samokształcenia. Wychowawca nie może zawsze towarzyszyć uczniowi. Kiedy jednak to robi, powinien wykazać się sprawnością długomyślności połączonej z cierpliwością, łagodnością i wyrozumiałością. Wychowanie wymaga od wychowanka nabycia wielu sprawności rozumu oraz woli, co często we współczesnej pedagogice jest pomijane. Wybiórczo zwrócimy uwagę na roztropność jako dzielność rozumu i długomyślność jako dzielność woli.

Pełną sprawność umysłu potrafiącego kierować całym postępowaniem człowieka w jego codziennym życiu nazywamy roztropnością ${ }^{13}$. Zrozumienie roli, jaką odgrywa cnota roztropności w dobrowolnym czynie ludzkim, jest możliwe przy uwzględnieniu wzajemnych relacji łączących poszczególne akty rozumu i woli. Z chwilą kiedy pomysł o czymś, co nam się podoba, przemieni się w umyśle w zamysł, który wzbudzi w woli zamiar zdobycia go, aktywność rozumu zostaje włączona w działania woli skłaniającej go do wykonania całego szeregu czynności znalezienia i wyboru odpowiednich środków prowadzących do zamierzonego celu oraz zastosowania ich $\mathrm{w}$ praktyce ${ }^{14}$. Zanim rozum uzna jakieś środki prowadzące do wyznaczonego celu za dogodne, winien wpierw rozważyć wszystkie dostępne możliwości, a następnie musi rozsądzić, który ze środków w danej chwili najlepiej mu odpowiada i dokonując wyboru, powziąc postanowienie, a następnie przystąpić do wykonania zamierzenia. Ogólnym celem, który nas do tego wyboru pobudza, jest pragnienie, aby nam było dobrze, a to jest związane z pożądaniem pełnego, doskonałego szczęścia, o którym pisał już Arystoteles w Etyce nikomachejskiej. Każdy chce być szczęśliwym, dlatego pragnie dla siebie najwyższego dobra, które ma mu zapewnić szczęśliwośćc ${ }^{15}$.

Umiar jest cechą każdej cnoty, chroni ją od niepożądanego nadmiaru lub niedostatku. Rozum winien być właściwie wychowany do sprawnego odnajdywania umiaru w różnorodnych, nieraz bardzo złożonych i zmiennych warunkach życia. Nie jest łatwo odnaleźć i zachować właściwą miarę określonej dzielności. Znalezienie i sprawne stosowanie umiaru w dziedzinie wszystkich cnót wiąże się z pokonywaniem przez rozum trudności wynikających z ogólnych praw naszej natury i otaczającego nas świata. W tym celu rozum winien być systematycznie wychowywany, a tym

\footnotetext{
${ }^{12}$ Tamże, 345 .

${ }^{13}$ Jacek Woroniecki, Katolicka etyka wychowawcza, t. II/1 (Lublin: Redakcja Wydawnictw KUL 1995), 1466. Szerzej o roztropności u Akwinaty, zob. św. Tomasz z Akwinu, Suma teologiczna, przekł. Stanisław Bełch, IIII, qu. 45-56 (Katolicki Ośrodek Wydawniczy "VERITAS" 4-8, PRAED MEWS, London, W.2 1960-1985).

14 Woroniecki, Katolicka t. I, 103-119. Szerzej o pobudkach woli, zamiarze, wyborze środków prowadzących do celu, namyśle, przyzwoleniu i działaniu woli w łączności z rozumem zob.: Św. Tomasz z Akwinu, Suma Teologiczna, przekł. Stanisław Bełch, I-II, qu. 9-14 (Katolicki Ośrodek Wydawniczy "VERITAS" 4-8, PRAED MEWS, London, W.2 1960-1985).

${ }^{15}$ Arystoteles, Etyka nikomachejska, przekł. Daniela Gromska, ks. I, 1098 b-1099 a, (Warszawa: PWN 2000), 90-92.
} 
samym usprawniany, by dojść do cnoty roztropności, opartej na rozwadze i rozsądku' ${ }^{16}$.

We współdziałaniu rozumu oraz woli zarówno w zakresie zamierzenia, jak i wykonania określonych działań, prowadzących do osiągnięcia upragnionego celu, potrzebna jest pilność, z jaką poszukuje się środków do jego osiągnięcia. Pragnienia celu nie można wzbudzić żadnym zewnętrznym przymusem, musi ono wypływać z ludzkiego wnętrza. Jeśli będzie zbyt silne, to wówczas istnieje obawa przed „pójścia na skróty”, czyli obrania pierwszych lepszych, na „chybił trafił” środków, co będzie wyrazem ludzkiej naiwności. Widać więc, że działanie woli jest tą siłą sprawczą, która winna kontrolować funkcjonowanie rozumu praktycznego w przestrzeganiu w życiu moralnym umiaru w rozwadze, rozsądku, a przede wszystkim w roztropności.

Woroniecki z władzami pożądawczymi łączy grupy cnót umiaru i męstwa. Do grupy dzielności męstwa zalicza: długomyślność, męczeństwo, cierpliwość, wielkoduszność, stałość i wytrwałość. Męstwo i pokrewne mu dzielności związane są z podtrzymywaniem wysiłku oraz niewycofywaniem się wobec zagrażającego zła lub wytrwałością potrzebną do pokonania trudności, jakie niekiedy się zdarzają przy zdobywaniu określonych dóbr. Zdaniem Woronieckiego cnota męstwa daje nam sprawność właściwego zachowania się wobec niebezpieczeństw, szczególnie tych, które zagrażają życiu, zdrowiu czy sławie ${ }^{17}$.

Najczęściej za szczyt męstwa uważa się męczeństwo, kiedy człowiek w obronie ideałów dobra i prawdy, ratowania innych w nieszczęśliwych wypadkach, ponosi śmierć. Męstwem zaś jest to, że w powyższych sytuacjach człowiek jest w stanie zaryzykować własnym życiem. Z kolei zadaniem stałości i wytrwałości jest umiejętne pokonywanie niespodziewanie wyłaniających się problemów dzięki zdobywaniu się na dodatkowy wysiłek, nieustępliwość w przezwyciężaniu trudności oraz trwaniu i nieodstępowaniu od powziętego przedsięwzięcia ${ }^{18}$. W wychowaniu, oprócz zdobywania sprawności stałości i wytrwałości, bardzo ważne są jednak cnoty cierpliwości, długomyślności i wielkoduszności.

Cnota cierpliwości, chociaż jest zbliżona do cnoty łagodności, to jednak należy do innego rodzaju. Łagodność jest cnotą panowania nad gniewem, cierpliwość zaś ma za zadanie opanować smutek oraz zniechęcenie i nie zezwolić na wycofywanie się z tego, co jest naszym obowiązkiem. Zdaniem Woronieckiego: „Cnota męstwa daje moc zniesienia z odwagą największego cierpienia, jakie zadaje śmierć, ale cierpienia najczęściej krótkotrwałego. Natomiast cierpliwość ma dać moc znoszenia o wiele mniejszych cierpień, ale za to trwających dłużej lub wracających częściej, a przy tym nieraz możliwych do uniknięcia przez zawrócenie z drogi, na którą się weszło i wyrzeczenie się celu, do którego się dążyło"19.

\footnotetext{
${ }^{16}$ Woroniecki, Katolicka, t. II/1, 22.

${ }^{17}$ Tamże, 424-427.

${ }^{18}$ Tamże, 442-444.

${ }^{19}$ Tamże, 439.
} 
Długomyślność jest tą cnotą, którą najczęściej błędnie się pojmuje, utożsamiając z cierpliwością, dlatego nie znajduje ona należytego miejsca $\mathrm{w}$ opisie ludzkich postaw. Prawdą jest, że istnieje bliskie pokrewieństwo między cierpliwością a długomyślnością, gdyż obie mają za zadanie panować nad zniechęceniem, wywołanym smutkiem z powodu jakiegoś zła. Jednak tym złem może być albo coś, co sprawia cierpienie lub jakąkolwiek nieprzyjemność, albo nieobecność jakiegoś dobra, którego pragniemy i oczekujemy, ale nie możemy się go doczekać. Cierpliwość uzbraja nas w radzeniu sobie z pojawiającym się konkretnym złem, a długomyślność pozwala poradzić sobie z nieobecnością spodziewanego dobra.

Zdaniem Woronieckiego $\mathrm{w}$ dziedzinie wychowania długomyślność ma wielką doniosłość: „można ją nazwać właściwą cnotą wychowawcy! Jest ona potrzebna w każdej pracy ludzkiej zakrojonej na dalszą metę i niepozwalającej się spodziewać natychmiastowych rezultatów. Nieraz będą się one opóźniać z racji różnych przeszkód, których nie da się przewidzieć i usunąć. Gdy idzie o wychowanie, przeszkody te mogą powstać w samym osobniku, który ma być wychowany, mianowicie w woli wychowanka, i to sprawia, że w tej dziedzinie człowiek jest narażony na tak bolesne zawody, jak w żadnej innej. Co więcej, kto nie ma mocno ugruntowanej długomyślności i zniechęceniu swemu daje wyraz ciągłym narzekaniem i besztaniem wychowanków, tylko jeszcze bardziej utrudnia sobie pracę i odwleka chwilę, gdy będzie się radował jej owocami. Wiemy dobrze, ile taki nastrój zniechęcenia u wychowawcy szerzy zniechęcenia w środowisku, które jest powierzone jego pieczy" ${ }^{20}$. W dziedzinie wychowania nie należy oczekiwać zbyt szybkich rezultatów własnej pracy. Nieraz nauczyciel jest zmuszony oglądać rezultaty przeciwne w stosunku do podejmowanych zamierzeń. Właściwe owoce podejmowanych działań wychowawczych mogą i najczęściej przychodzą dopiero w przyszłości. Dlatego każdy wychowawca winien być uzbrojony w ową cnotę długomyślności. Daje ona głębokie przekonanie o skuteczności i ważności ciągłego podejmowania wysiłku na rzecz dobra każdego wychowanka.

Pedagogika Woronieckiego, przyjmując założenia aretologiczne, dąży do osiągnięcia greckiego ideału człowieka moralnie dobrego (kalos kagathos), który zachowując ład i panowanie nad światem własnego wnętrza, ćwiczy się $\mathrm{w}$ doskonaleniu sprawności moralnych ${ }^{21}$. W pedagogice tej zwraca się uwagę na jedność i nierozerwalność wszystkich cnót. Brak jakiejś sprawności wprowadza nieuporządkowanie w świat działań ludzkich i może stać się przyczyną rozwoju wad moralnych.

Przedstawiając aretologiczne założenia pedagogiki w zarysie, należy zgodzić się z Mikołajem Krasnodębskim, iż pedagogika aretologiczna Woronieckiego nadal

\footnotetext{
${ }^{20}$ Tamże, 441-442.

${ }^{21}$ Interesującym opracowaniem greckiej paidei jest praca Mikołaja Krasnodębskiego, Zarys dziejów ateńskiej historii wychowania. Paideia od Sokratesa do Zenona (Warszawa: Engram-Difin 2011); zob. także: Barbara Kiereś, O personalizm w pedagogice. Studia i szkice z teorii wychowania (Lublin: Fundacja Servire Veritati IEN 2009), 42-50.
} 
stanowi cenną inspirację do opracowania aksjologicznych założeń wychowania realistycznego ${ }^{22}$.

\section{Pedagogiczny uniwersalizm}

Realizm pedagogiczny lączony jest z obiektywizmem poznawczym i ontologicznym, stanowiąc dla Woronieckiego podstawę do najogólniejszej kategorii, jaką jest uniwersalizm pedagogiczny ${ }^{23}$. Woroniecki był przekonany, że jeśli przedmiotem rozumu nie będzie wspólny dla nas wszystkich byt, ale przejaw tego bytu w samym rozumie, czyli myśli o nim, to z konieczności zanika między ludźmi wspólna, spajająca w jedną całość więź poznawcza. Stajemy wówczas wobec krańcowego indywidualizmu, subiektywizmu i anarchizmu, gdyż dla każdego przedmiotem poznania są jego własne myśli niedostępne poznaniu drugiego człowieka ${ }^{24}$. Stanowisko realizmu pedagogicznego przyjęte przez Woronieckiego zdaniem Janiny Kostkiewicz „zmusza do utrzymania nieustannego kontaktu z rzeczywistością świata, który jest niewyczerpalny dla umysłu ludzkiego"25.

Uniwersalizm pedagogiczny Woronieckiego jest transcendentny, powszechny, otwarty i krytyczny. Wchłania (po wcześniejszej krytyce) wiedzę prawdziwą, rozproszoną w systemach filozoficznych i pedagogicznych. Odrzuca natomiast wszelką ich fragmentaryczność, ułamkowość oraz jednostronny ekskluzywizm²6.

Przedmiotem poznania ludzkiego jest rzeczywistość w całej swej rozciągłości: zjawiska społeczne i przyrodnicze, idee zawarte w systemach filozoficzno-pedagogicznych, nasze własne przeżycia. W uniwersalizmie poznane zasady bytu: tożsamość, niesprzeczność, przyczynowość i celowość oraz zasady działania, z fundamentalną zasadą bonum faciendum malum vitatdum, stają się podstawą wiedzy i aktywności. $\mathrm{Z}$ tych bowiem zasad można wyprowadzić całą filozofię praktyczną i teoretyczną. Zwróciłem uwagę na filozofię praktyczną, etykę, w której centralne miejsce zajmuje pedagogika. Poniżej przedstawię metafilozoficzne ujęcie uniwersalizmu wiedzy pedagogicznej.

Uniwersalizm wiedzy pedagogicznej u Woronieckiego wiąże się z czterema ściśle z sobą związanymi składnikami wszelkiej wiedzy. Pierwszy z nich stanowi

\footnotetext{
${ }^{22}$ Mikołaj Krasnodębski, Człowiek i paideia. Realistyczne podstawy filozofii wychowania (Warszawa: Wydawnictwo Szkoły Wyższej Przymierza Rodzin w Warszawie 2009), 105-125. Krasnodębski w pracy Człowiek i Paideia analizuje przede wszystkim założenia filozoficzne pedagogiki.

${ }^{23} \mathrm{Na}$ uniwersalizm pedagogiczny u Woronieckiego zwraca uwagę Feliks W. Bednarski OP, Uniwersalizm pedagogiczny O. Jacka Woronieckiego, w: tegoż, Zagadnienia pedagogiczne (Londyn: Katolicki Ośrodek Wydawniczy Veritas 1982), 59-75.

${ }^{24}$ Jacek Woroniecki, Katolickość tomizmu (Lublin: Uniwersytet Lubelski 1924), 72.

${ }^{25}$ Janina Kostkiewicz, Kierunki i koncepcje pedagogiki katolickiej w Polsce 1918-1939 (Kraków: Oficyna Wydawnicza „Impuls” 2013), 104.

${ }^{26}$ Woroniecki, Katolickość , 8-9.
} 
przyczynę materialną pedagogiki, uwzględnia zakres i treść jej przedmiotu ${ }^{27}$. Drugi składnik stanowi przyczynę celową, gdyż przedmiotem staje się przedmiotowy cel pedagogiki. Trzecim jest przyczyna formalna, która stanowi o istocie pedagogiki, a czwarty - dotyczy metody i w tym zakresie stanowi przyczynę sprawczą wiedzy pedagogicznej ${ }^{28}$. Z racji tego, że treść, jak i metoda zdobywania wiedzy pedagogicznej są pochodnymi pozostałych składników wiedzy, można mówić o uniwersalizmie Woronieckiego w zakresie przedmiotu pedagogiki, jej przedmiotowego celu oraz formalnej racji jej przedmiotu.

Przedmiotem pedagogiki jest wszechstronne objęcie samego wychowania przy uwzględnieniu w miarę potrzeby wszystkich dotyczących go czynników, między innymi upowszechniania oświaty oraz zapewnienia integralnego wychowania dla wszystkich warstw społecznych. Wyraża się to zarówno w sprawiedliwości współdzielczej, „przejawiającej się w mądrym ustawodawstwie społecznym, a następnie i rozdzielczej, opartej na tym ustawodawstwie, ale idącej dalej, bo przenikającej i do obyczajów. Gdy będą one głębiej przeniknięte duchem hojności, ofiarności i wspaniałomyślności, wtedy dopiero wszelkie zarządzenia zmierzające do równomiernego udziału obywateli we wspólnym dobrobycie zaczną dawać wyniki”" Żąda się więc, aby społeczność objęła troską wychowawczą wszystkie osoby zdolne do doskonalenia samych siebie. Uniwersalizm pedagogiczny Woronieckiego zabrania wykluczania kogokolwiek z rzetelnej opieki wychowawczej. Tak rozumiana paidea zapewnia wszystkim obywatelom realne możliwości doskonalenia się oraz zdobywania odpowiednich kompetencji i doskonalenia umiejętności stosownie do indywidualnych uzdolnień oraz potrzeb pozostających w zgodzie z dobrem ogółu.

Uniwersalizm pedagogiczny ze względu na zakres przedmiotu wiedzy wymaga wszechstronnego oddziaływania wychowawczego, nie ograniczającego się jedynie do kształcenia. Pod tym względem Woroniecki krytykował tak zwany „intelektualizm moralny", pojmując go jako wypaczony pogląd dotyczący kierowniczej roli rozumu, a nie woli. „Polega on na tym, że rozumowi nie tylko przypisuje się pierwszeństwo przed wolą, ale że całą działalność moralną sprowadza się niemal wyłącznie do rozumowania, z wykluczeniem działalności czynników pożądawczych, a przede wszystkim woli" ${ }^{\circ}$. Tak rozumiany intelektualizm moralny doprowadzil do ukonstytuowania się stanowisk indywidualistycznych, które są zaprzeczeniem uniwersalizmu. W konsekwencji zastąpiono wychowanie samym nauczaniem, co doprowadziło do ograniczenia, a w wielu wypadkach do nieuwzględniania roli czynników społecznych w wychowaniu.

${ }^{27} \mathrm{~W}$ tomizmie treść przedmiotu jest rozumiana jako przedmiot materialny wiedzy. Z kolei czterem składnikom wiedzy odpowiadają cztery przyczyny, zasady wszelkiego bytu: materialna, formalna, sprawcza i celowa.

${ }^{28}$ Bednarski, Uniwersalizm, 61.

29 Jacek Woroniecki, Etyka spoleczna (maszynopis), Magazyn Biblioteki Instytutu Teologicznego w Bielsku-Białej nr 7615, 280.

${ }^{30}$ Woroniecki, Katolicka, t. I, 19. 
W etyce wychowawczej Woroniecki starał się nie pominąc żadnego z ważniejszych czynników wychowania indywidualnego i społecznego, moralnego i religijnego, umysłowego i fizycznego, technicznego i estetycznego. Uwzględnianie tak wielu elementów wynikało z obiektywnego poznania natury ludzkiej i przekonania, „że człowiek ma cały szereg wrodzonych usprawnień [...] do życia, do wolności, do wiedzy, do własności, do sławy, do małżeństwa i wszystkiego co z tego wypływa" ${ }^{31}$. Wrodzone usprawnienia są tkwiącymi w człowieku potencjalnościami, które pod wpływem licznych czynników zewnętrznych i pracy nad sobą urzeczywistniają się w sposób plastyczny, ukazując indywidualność i różnorodność rozwoju osobowego ${ }^{32}$.

Ze względu na przedmiotowy cel pedagogiki uniwersalność polega na jej dążeniu do realnego i najwyżej stojącego dobra-celu przy wykorzystaniu możliwych, godziwych środków oraz metod prowadzących do jego osiągnięcia. Bezpośrednim celem pedagogiki jest poznanie i dążenie do jego osiągnięcia, a więc wykorzystania władzy poznawczej, jaką jest rozum oraz władzy działania, jaką jest wola.

Woroniecki wyróżnił cel nauki o wychowaniu, którym jest bezpośrednia wiedza o tym, jak należy wychowywać i dlaczego w ten sposób, oraz cel samego wychowania, który dotyczy doskonalenia osobowości przez jej usprawnianie. Wiedząc, że pedagogika jest centralną częścią etyki, należy przyjąć, iż cel różnicujący gatunkowo czynność i sprawność wiedzy pedagogicznej jest ten sam i sprowadza się do tego, aby wiedzieć jak doskonalić osobowość. W tym metafilozoficznym zakresie Woroniecki przedstawia schemat podziału wiedzy o czynnościach jej wyodrębniania. Wyróżnia wiedzę: teoretyczną, praktyczno-teoretyczną, praktyczno-habitualną i praktyczno-aktualną, którą jest roztropność33. Nie wdając się w szczegóły owego podziału, ze względu na ograniczoność zakresu podjętej w artykule tematyki realizmu etyki wychowawczej, należy jednak zauważyć małą jego przejrzystość i apodyktyczność w określaniu ze względu na cel przynależności pedagogiki jako nauki o wychowaniu tylko do wiedzy praktyczno-habitualnej a samego wychowania - do wiedzy praktyczno-aktualnej.

O uniwersalności pedagogiki zaświadcza także formalna racja jej przedmiotu. Mam tu na uwadze zasady, na podstawie których uzasadnia się właściwe twierdzenia pedagogiki. Są one jej punktem wyjścia, podczas gdy przedmiotowy cel jest punktem dojścia, a zakres i treść przedmiotu jest jej materialną bazą. Zasady te umożliwiają wszechstronne wychowanie i działanie wychowanka pod warunkiem właściwej towarzyszącej mu postawy wychowawcy, ukształtowanej na podstawie zdobytej i opanowanej wiedzy oraz osobistego doświadczenia wychowawczego. Wychowawca powinien, jak pisze Woroniecki w Gawędzie o gawędzeniu, „mieć oczy szeroko otwarte na wszystko, co się na świecie dzieje i nie pozwalać przesłaniać sobie tego cudownego widoku niczym, nawet książką. [...] Książka przy niesłychanych

\footnotetext{
${ }^{31}$ Woroniecki, Etyka, 2.

${ }^{32}$ Woroniecki, Katolicka, t. I, 329-332. Szerzej zob.: Kostkiewicz, Kierunki, 107-111.

${ }^{33}$ Woroniecki, Katolicka, t. I, 35-44.
} 
korzyściach, które przyniosła ludzkości, niejednemu wyrządziła więcej zła niż dobra, przesłaniając mu świat. [...] Ilu mamy takich ludzi, dla których świat mógłby nie istnieć, byleby były biblioteki. Ktoś, kto nie pomyślał o wypełnieniu ram swego wykształcenia doświadczeniem życiowym [...] będzie tylko młócił pustą słomę ogólników i rozwijał abstrakcyjne pojęcia [...] będzie nudził zamiast interesować i zachęcać do czynu"34. Z powyższej wypowiedzi Woronieckiego przebija krytyczny realizm w ocenie postaw tych, którzy biorą na siebie odpowiedzialność za bycie wychowawcą.

Streszczenie: W niniejszym artykule ukazano, iż koncepcja wychowania Woronieckiego odwołuje się do dorobku myśli klasycznej oraz chrześcijańskiej. Osadzona jest na realizmie ontologicznym i teoriopoznawczym w głoszeniu konieczności integralnego, uniwersalistycznego wychowania i kształcenia człowieka. Pedagogika ta przyjmuje założenia antropologii filozoficznej, a także etyki arystotelesowsko-tomistycznej, które ukazują, kim jest człowiek i czym jest dobro moralne jako cel ludzkiego dążenia. Cel ten jest jednocześnie celem pedagogiki, któremu podporządkowane są wszystkie zadania i sposoby wspierania wychowanka. Poglądom pedagogicznym Woronieckiego przypisać należy, oprócz kategorii realizmu, ogólniejszą kategorię uniwersalności. Pedagogika rozumiana jako etyka wychowawcza zakłada integralne wychowanie i kształcenie człowieka, jest zatem skierowana do wszystkich. Realizm tej pedagogiki osadza się na przeświadczeniu, iż każdy powinien w życiu osobowym i społecznym doskonalić się z racji swej potencjalności, którą należy urzeczywistnić w pracy nas sobą samym.

Słowa kluczowe: Jacek Woroniecki, etyka wychowawcza, neotomizm, realizm ontologiczny, realizm epistemologiczny, aretologia

\section{Bibliografia}

Arystoteles. Etyka nikomachejska. Przekład. Daniela Gromska. Warszawa: PWN, 2000.

Bednarski, Feliks W. „Uniwersalizm pedagogiczny O. Jacka Woronieckiego”. W: tegoż, Zagadnienia pedagogiczne. Londyn: Katolicki Ośrodek Wydawniczy Veritas, 1982.

Bednarski, Feliks W. Zagadnienia pedagogiczne. Londyn: Katolicki Ośrodek Wydawniczy Veritas, 1982.

Gałkowski, Stanisław. Ku dobru. Aktualność filozofii wychowania Jacka Woronieckiego. Rzeszów: Wydawnictwo Wyższej Szkoły Pedagogicznej, 1998.

Horowski, Jarosław. „Sprawność czy kompetencje moralne?”. Paedagogia Christiana 1 (2012): 191-208.

Jaśtal, Jacek. Natura cnoty. Problematyka emocji w neoarystotelesowskiej etyce cnót. Kraków: Księgarnia Akademicka, 2009.

Kiereś, Barbara. O personalizm w pedagogice. Studia i szkice z teorï wychowania. Lublin: Fundacja Servire Veritati IEN, 2009.

Kostkiewicz, Janina. „Aksjologiczne podstawy katolickich koncepcji pedagogicznych”. W: Chrześcijańskie inspiracje w pedagogice, red. Janina Kostkiewicz, 13-29. Kraków: Wydawnictwo UJ, 2011.

${ }^{34}$ Jacek Woroniecki, Gawęda o gawędzeniu (Poznań: Księgarnia Świętego Wojciecha 1920), 13, 18. 
Kostkiewicz, Janina. Kierunki i koncepcje pedagogiki katolickiej w Polsce 1918-1939. Kraków: Oficyna wydawnicza „Impuls”, 2013.

Krasnodębski, Mikołaj. Człowiek i Paideia. Realistyczne podstawy filozofii wychowania. Warszawa: Wydawnictwo Szkoły Wyższej Przymierza Rodzin w Warszawie, 2009.

Krasnodębski, Mikołaj. „O możliwości zbudowania realistycznej filozofii wychowania woparciu o personalizm i tomizm”. Horyzonty Wychowania 18 (2009), 137-168.

Krasnodębski, Mikołaj. „Pedagogika Jacka Woronieckiego i Feliksa Wojciecha Bednarskiego jako egzemplifikacja etyki tomizmu tradycyjnego". Studia Etckie 11 (2009): 29-58.

Krasnodębski, Mikołaj. Zarys dziejów ateńskiej historii wychowania. Paideia od Sokratesa do Zenona. Warszawa: Engram - Difin, 2011.

MacIntyre, Alasdair. Dziedzictwo cnoty. Studium z teorii moralności. Przekład Adam Chmielewski. Warszawa: PWN, 1996.

Sztobryn, Sławomir. „Historia wychowania”. W: Pedagogika. Podstawy nauk o wychowaniu, t. I, red. Bogusław Śliwerski. Gdańsk: GWP, 2006.

Szutta, Natasza. „Dyskusja z sytuacjonistyczną krytyką etyki cnót. Odpowiedź na zarzuty Gilberta Harmana”. Diametros 31 (2012): 88-112.

Szutta, Natasza. „Statut współczesnej etyki cnót”. Diametros 1 (2004): 70-84.

Święty Tomasz z Akwinu. Suma teologiczna. Przekład Stanisław Bełch. Londyn: Nakładem Katolickiego Ośrodka Wydawniczego Veritas, 1960-1985.

Woroniecki, Jacek. Etyka spoleczna [maszynopis]. Magazyn Biblioteki Instytutu Teologicznego w BielskuBiałej, $\mathrm{nr} 7615$.

Woroniecki, Jacek. Gawęda o gawędzeniu. Poznań: Księgarnia Świętego Wojciecha, 1920.

Woroniecki, Jacek. Katolicka etyka wychowawcza, t. I oraz t. II/1. Lublin: Redakcja Wydawnictw KUL, 1995.

Woroniecki, Jacek. Katolickość tomizmu. Lublin: Uniwersytet Lubelski, 1924.

Woroniecki, Jacek. Umiejętność rzq̨dzenia i rozkazywania. Poznań: Albertinum, 1947.

Woroniecki, Jacek. Wychowanie cztowieka. Pisma wybrane. Kraków: Znak, 1961. 